\title{
Development of A Preschool Teacher's Guidance Qualifications Scale and Its Psychometric Properties
}

\author{
Hülya Bilgin \\ Correspondence: Ataturk Faculty of Education, Marmara University, Istanbul, Turkey. \\ Received: June 6, 2017 \\ doi:10.11114/jets.v5i9.2467 \\ Accepted: August 6, 2017 \\ Online Published: August 7, 2017 \\ URL: https://doi.org/10.11114/jets.v5i9.2467
}

\begin{abstract}
The goal of this study is to develop a Guidance Qualification Scale for Preschool Teachers and examine the validity and reliability of the scale. The research was conducted with 374 teachers working in preschools in Istanbul and they were chosen by the random sampling method. Factor analysis was carried out for the construct validity of the scale. Internal consistency coefficients and test-retest reliabilities were examined and item analysis was performed for reliability studies. As a result of the factor analysis, 59 items which explained $55,989 \%$ of the total variance (Total Variance Explained $45,050 \%$ ), were obtained under four factors. When the factor weights of the scale are examined, items were found to have weight values ranging from .746 to .453. Cronbach's Alpha internal consistency coefficients of the "Preschool Teacher's Guidance Qualifications Scale" were found to be .977 for the total scale, .954 for the "Supporting Educational Development and Interpersonal Relationships" sub-dimension, .943 for the "Supporting Individual Development and Orientation" sub-dimension, .904 for the "Self-acceptance, Support for Self and Social Development" sub-dimension and .909 for the "Recognizing Individuals, Identifying Problems and Supporting Parents" sub-dimension. Also, the test-retest reliability study of the scale was conducted with 44 teachers. According to the results of the t-test applied for differences between the average item scores of upper $27 \%$ and lower $27 \%$ groups of items on (in?) the scale, all differences were found to be significantly in favor of the upper $27 \%$ group. In light of these findings, it can be said that the "Preschool Teacher's Guidance Qualifications Scale" can be used as a valid and reliable measurement tool in the field of education.
\end{abstract}

Keywords: guidance, preschool education, preschool teacher, validity, reliability

\section{Introduction}

Considering the entire lifetime of humans, beginning with the pre-natal period, some periods are known to have more critical roles than others in terms of psychological, physiological, cognitive and sociological aspects. Preschool years involving the first 6 years of life are so important and critical that they cannot be left to chance in terms of the formation of personality, capacity building, socialization, self-actualization and adaptation to school environment.

Some studies show that, when considering the age and developmental level of children in this period, there are some developmental tasks for children to fulfill and those who cannot complete a developmental level successfully will not be able to succeed in the next developmental task either. Within this context, it is inevitable to refer to guidance services in order to support and facilitate children's successful completion of the developmental tasks (Akgun E, 2010).

Guidance services that should be planned for children in the preschool period should fulfill the functions of supporting children's development, eliminating the differences originating from the environment in which they live, preparing them for the next step of the education, improving the relationships necessary for personal and social life which are compatible with their environments and ensuring that they gain regular studying skills and practices.

The primary goal of the developmental guidance model is to support the students' "development of life career". Life career development represents the development of one's self by integrating the roles, environments and incidents an individual is going to encounter in life. Developmental based school guidance services beginning at preschool and continuing through higher education aim to ensure that students gain various life skills (self-knowledge, self-respect, effective communication, responsibility, setting an objective, decision making-problem solving, career planning etc.) and include work that is performed for the purpose of preventing potential problems, in a planned and programmed way. Classroom guidance is an intervention carried out in classrooms which provides students the opportunity to gain numerous qualifications in a planned way (Nazli, 2013).

Guidance and counseling services support the individual's self-realization and development as a whole (Gokcakan, 
2008). When the services within the scope of the guidance are taken into consideration, it can be seen that it is important for students to be benefiting from guidance services that are appropriate for the developmental characteristics of the respective period in every step of the education. Education is a process and the fact that development is continuous has made it necessary for guidance services to undertake the function of "facilitating development and assisting in the achievement of the developmental tasks" in every level of education. Developmental guidance adopted with this perspective is based on the fact that the individual is in a continuous process of development, $\mathrm{s} / \mathrm{he}$ has some developmental tasks that $\mathrm{s} / \mathrm{he}$ is expected to fulfill as a requirement of his/her age and the developmental period s/he's in and that those who have succeeded in a developmental level will have better success in the developmental tasks of the next level. In this approach, it is aimed to provide guidance services in a systematic and programmed way to facilitate and support the children's successful fulfillment of their developmental tasks (Gokcakan, 2008; Yesilyaprak, 2004). The developmental guidance services in this period must be complementary to the education services at school and an integral part of such services (Ginter, Scalise, and Presse, 1990, Hoffman, 1991, Yesilyaprak, 2003).

In this period guidance services from a personal perspective, include activities directed towards achieving the goals of self-acceptance, development of self-esteem, creation of the self-concept and provision of socialization for the child. From an educational perspective, the goals of integration with school and readiness for primary education are essential. In this sense, it is aimed to help the child to love school, to be motivated for education and to gain some basic skills. In the vocational guidance field, activities aimed at the child's fulfillment of period-specific vocational developmental tasks are planned since this period is accepted as the beginning of the vocational developmental process (Yesilyaprak, 1995). All these activities are implemented by integrating them with the relevant units. Naturally, goals that are planned through games, drama activities and physical exercises are tried to be realized. In this period, the teacher should pay close attention and display affection to the child, be a good role model, not be over protective and have a close relationship and be in a tight cooperation with the family. As a good observer, the teacher keeps track of the child's development, keeps the relevant records, takes precautions in cases where things can go wrong and search for solutions to problems.

In addition to being the classroom teacher, the preschool teacher is the natural leader and guidance teacher of his/her classroom.

A kindergarten/preschool teacher with an understanding of guidance tries to create a free, comfortable, warm and secure atmosphere in this period to ensure the child's healthy development in every aspect, his/her adaptation to the school environment, and his/her realization of their potential. First of all, she or he provides the physical and social environment necessary for the healthy development. In this environment, children learn to get to know themselves in peer groups, to develop the strength and skills necessary to maintain their lives and the rules for living together. Because only children whose developmental needs are met can be healthy and compatible (Yesilyaprak, 2004).

In the school environment, teachers are the individuals who interact most with children. Because they are in a deep and long-term relationship with the children, they know them better, detect problems earlier, form a direct relationship with parents and identify risk factors easier. This situation is the clearest indicator of teachers' role in prevention (Demir, 2010).

Since 0-6 age period is a significant one in terms of all the child's developmental areas, teachers have important roles and duties. During the preschool period, the child is open to all stimuli coming from the environment. For this reason, education provided in this period is very essential for the child. The child's gained habit of displaying the appropriate behaviors and the positive development of all his/her developmental areas, reveal the importance of this period and the qualifications of the teachers who will provide education during this period.

In the global age, teachers should have sufficient preparation and skills to provide students with the highest standard of education (Hammond, 2005). In the area of school, family and society relationships, it is considered to be a requirement for teachers to recognize the growth and the development characteristics of the students, to provide opportunities that support their intellectual, social, emotional and physical development, to provide guidance to students and to be well enough in the area of human relations (NJDOE, 2004: 17). The expectation that teachers who are acknowledged to have a key role in developing these characteristics consist of qualified individuals who are able to monitor changes and developments and ensure that work is realized in an effective and efficient way in terms of quality and quantity, is important in terms of education. (Basar, 2000: 129; Kavuran, 2003: 168; Sen and Erisen, 2002: 100).

Senemoglu (1998), who mentions the importance of teachers working in preschool and primary education years states that "Preschool and classroom teachers are people who nurture the cognitive development of future generations by having an impact on children in these periods of great influence on the individual's cognitive development, draw the frame for and start shaping the attitudes of individuals towards self, the society and the outside world and speed up the development of the skills of communication, research, analytical thinking, problem solving, creativity, and aesthetic which will affect the way future generations will live to a great extent."

Guidance should be applied in every step of the education when it is examined in terms of the qualifications it helps people 
to gain. People might encounter different kinds of problems in different stages of life and their solutions for these problems will be different in each stage. Therefore, when looking at educational levels different guidance practices will be needed in preschool education, primary education and higher education. In cases where these needs are not met, the individual might make inappropriate choices in education life and might be late for self-actualization. For this reason, it is essential for teachers who work at each level to apply the necessary practices in personal, educational and vocational guidance fields of their students. Especially in the preschool period where the individual begins to recognize him/herself, a great deal of attention must be paid to guidance practices. As a part of the guiding practices of the play-age child it is the primary function of the teacher to prepare an educational environment appropriate for the development of the child in the preschool education period and to make the necessary contribution to ensure that this development is carried out at school, in the family and in other environments in the best possible way. During this period of transition from being a play-age child to a school child which is considered to be a starting point, the basic comprehension and attitudes the child will gain will have an impact on the whole educational process (Yesilyaprak, 2010: 80).

In our country, the formation of psychological counsellors who will work at preschool education institutions and primary education institutions is not provided prevalently since it's considered that they may mostly work at secondary education institutions. As a result of this the PCG services are also not provided prevalently at preschool and primary education (Dogan, 2001; Yuksel- Sahin, 2008).

Especially nowadays, as demand and expectations for guidance services increase, it can be seen that school counselors cannot take this burden alone. With the participation of the teachers, more students will benefit from guidance services. For this reason, teachers are required to have active involvement especially while carrying out classroom guidance activities (Ergin, 2010).

Guidance teachers who work in preschool institutions are not in the desired number yet. It will be an important long-term solution to improve the guidance and counseling knowledge and skills of preschool teachers so that preschool children can benefit from guidance services until the desired number is reached.

It is within the understanding of today's education that teachers who work in the preschool period and who play an important role in the education of children, are qualified and well-equipped individuals who can meet the needs of their students in many aspects. It is believed that the identification and improvement of the preschool teachers' competence levels will help our teachers to experience a more successful guidance process and will help increase the quality of preschool education. At the same time, it is considered that the developed scale will give light to academic studies that will be carried out in the field.

\section{Method}

\subsection{Population and Sample}

The population of the research includes preschool teachers working in Istanbul in the academic year of 2015-2016.

In order to carry out the reliability and validity study of the "Preschool Teacher's Guidance Qualifications Scale", an appropriate number for scale development criteria was determined from the preschool teachers working in public and private schools in the population determined above via the stratified sampling method. In the study group, there were 374 teachers in total. 121 of them were working in independent preschools, 167 of them were working in primary school nursery class, 84 of them were working in preschool/kindergarten/day care centers.

\subsection{Collection of Data}

Data collected from 374 teachers working in the field were subjected to statistical processing through the data collection tool "Preschool Teacher's Guidance Qualification Scale" developed by the researcher. A minimum of five participants for each variable (item) is required for the reliability and validity study of the "Preschool Teacher's Guidance Qualification Scale" (Coakes, 2005).

\subsection{Data Collection Tool}

"Guidance Qualification Scale for Preschool Teacher Candidates" developed by Bilgin (2015) was revised and renamed as "Preschool Teacher's Guidance Qualifications Scale" and used as a data collection tool in the study. As a result of the statistical analyzes, the original 72 items of the scale were reduced to 59 items.

As a result of the factor analysis, 59 items which explained 55,989\% of the total variance (Total Variance Explained $45,050 \%$ ) and which were collected under four factors were obtained. When the factor weights of the scale were examined, it was seen that they ranked between .746 and .453. The Cronbach's Alpha internal consistency coefficients of Preschool Teacher's Guidance Qualifications Scale were found to be .977 for the whole scale, .954 for Factor1:"Supporting Educational Development and Interpersonal Relationships" sub-dimension, 943 for Factor 2:"Supporting Individual Development and Orientation" sub-dimension, .904 for Factor 3: "Self-acceptance, Support for Self and Social 
Development" sub-dimension, .909 for Factor 4: "Recognizing Individuals, Identifying Problems and Supporting Parents" sub-dimension. In addition, the test-retest reliability study of the scale was conducted with 44 teachers. The scale form was prepared in the form of a 5-point Likert type [(1) Totally Disagree, (5) Totally Agree] grading scale.

\subsection{Validity and Reliability Studies}

Factor analysis method was used to identify the factor structure and subscales of 'Preschool Teacher's Guidance Qualifications Scale". Factor analysis is a technique of reducing large numbers of variables into smaller sets and putting them together under specific factors. In factor analysis, mostly exploratory factor analysis is used (Buyukozturk, 2012; Coakes, 2005; Grant and Fabrigar, 2007). Exploratory factor analysis (EFA) is a statistical method used to find out the basic correlation structure between observed variables and the aim is to define this structure (Grant and Fabrigar, 2007). In addition, exploratory factor analysis is used to test whether the items on a scale are divided into smaller number of factors and whether a tool is one-dimensional (Balci, 1997). For this reason, EFA is aimed at revealing the factors formed by the items on the scale (Buyukozturk, 2002).

For reliability studies, Cronbach's Alpha internal consistency coefficients and test-retest reliability coefficients of "Preschool Teacher's Guidance Qualifications Scale" were examined. Also, by using t-test with corrected item-total score for item analysis, the significance of the differences between item averages of upper \%27 and lower \%27 groups was examined. The significance level of all statistical procedures used in the study was accepted as .01 and an appropriate package program was used for the analyses.

\section{Findings}

The psychometric characteristics of the teachers who participated in the research along with the findings of the validity and reliability studies of the "Preschool Teacher's Guidance Qualification Scale" are provided below.

Table 1. Psychometric Characteristics of Teachers Who Participated in the Research

\begin{tabular}{|c|c|c|}
\hline Gender & $\mathbf{N}$ & $\%$ \\
\hline Female & 361 & 96,5 \\
\hline Male & 6 & 1,6 \\
\hline Missing Data & 7 & 1,9 \\
\hline Total & 374 & 100,0 \\
\hline Age & $\mathbf{N}$ & $\%$ \\
\hline 20 years of age and under & 8 & 2,1 \\
\hline $21-25$ years of age & 100 & 26,7 \\
\hline $26-30$ years of age & 104 & 27,8 \\
\hline $31-35$ years of age & 93 & 24,9 \\
\hline $36-40$ years of age & 33 & 8,8 \\
\hline 41 years of age and over & 32 & 8,6 \\
\hline Missing Data & 4 & 1,1 \\
\hline Total & 374 & 100,0 \\
\hline Marital Status & $\mathbf{N}$ & $\%$ \\
\hline Single & 162 & 43,3 \\
\hline Married & 209 & 55,9 \\
\hline Missing Data & 2 & 0,5 \\
\hline Total & 374 & 100,0 \\
\hline Child ownership & $\mathbf{N}$ & $\%$ \\
\hline With child & 212 & 56,7 \\
\hline Without child & 154 & 41,2 \\
\hline Missing Data & 8 & 2,1 \\
\hline Total & 374 & 100,0 \\
\hline Graduation Status & $\mathbf{N}$ & $\%$ \\
\hline High School & 2 & 0,5 \\
\hline $\begin{array}{l}\text { Vocational High School Child } \\
\text { Development }\end{array}$ & 52 & 13,9 \\
\hline $\begin{array}{l}\text { Child Development Associate } \\
\text { Degree }\end{array}$ & 53 & 14,2 \\
\hline $\begin{array}{l}\text { Preschool Education } \\
\text { education) }\end{array}$ & 29 & 7,8 \\
\hline Preschool Education & 199 & 53,2 \\
\hline Master Degree & 13 & 3,5 \\
\hline Currently Studying & 16 & 4,3 \\
\hline
\end{tabular}




\begin{tabular}{|c|c|c|}
\hline Other & 9 & 2,4 \\
\hline Total & 374 & 100,0 \\
\hline Vocational Experience & $\mathbf{N}$ & $\%$ \\
\hline $0-1$ year & 24 & 6,4 \\
\hline $1-5$ years & 137 & 36,6 \\
\hline $6-10$ years & 120 & 32,1 \\
\hline $11-15$ years & 62 & 16,6 \\
\hline 16 years and over & 28 & 7,5 \\
\hline Missing Data & 1 & 0,3 \\
\hline Total & 374 & 100,0 \\
\hline Institution Type & $\mathbf{N}$ & $\%$ \\
\hline Independent Preschool & 121 & 32,4 \\
\hline $\begin{array}{l}\text { Primary School nursery class } \\
\text { Private }\end{array}$ & 167 & 44,7 \\
\hline $\begin{array}{l}\text { Preschool/kindergarten/daycare } \\
\text { center }\end{array}$ & 84 & 22,5 \\
\hline Missing Data & 2 & 0,4 \\
\hline Total & 374 & 100,0 \\
\hline Socio-cultural level & $\mathbf{N}$ & $\%$ \\
\hline Low & 18 & 4,8 \\
\hline Middle & 263 & 70,3 \\
\hline High & 87 & 23,3 \\
\hline Missing data & 6 & 1,6 \\
\hline Total & 374 & 100,0 \\
\hline Investigated Age Group & $\mathbf{N}$ & $\%$ \\
\hline Under 48 months & 32 & 8,6 \\
\hline $48-60$ months & 191 & 51,1 \\
\hline $60-72$ months & 120 & 32,1 \\
\hline $36-72$ months mixed & 25 & 6,7 \\
\hline Missing Data & 6 & 1,6 \\
\hline Total & 374 & 100,0 \\
\hline Number of Students in Class & $\mathbf{N}$ & $\%$ \\
\hline 10 and less & 19 & 5,1 \\
\hline $11-15$ students & 82 & 21,9 \\
\hline $16-20$ students & 162 & 43,3 \\
\hline $21-25$ students & 97 & 25,9 \\
\hline 26 and more & 10 & 2,7 \\
\hline Missing Data & 4 & 1,1 \\
\hline Total & 374 & 100,0 \\
\hline Classroom Counselor in School & $\mathbf{N}$ & $\%$ \\
\hline Available & 280 & 74,9 \\
\hline Not Available & 89 & 23,8 \\
\hline Missing Data & 5 & 1,3 \\
\hline Total & 374 & 100,0 \\
\hline
\end{tabular}

When Table 1 is examined it can be seen that $96,5 \%$ of the teachers who participated in the research were female, $27,8 \%$ of them were in the age range of $26-30$ years, $55,9 \%$ of them were married, $56,7 \%$ of them were adults with children, $53,2 \%$ of them were graduates of Preschool Teaching, 36,6\% of them had a professional experience of $1-5$ years, $44,7 \%$ of them were working as a nursery classroom teacher at a primary school, $70,3 \%$ of them were working at schools at a middle socio-cultural level, $51,1 \%$ of them were working with children aged between $48-60$ months, $43,3 \%$ of them were providing education up to $16-20$ students in a classroom and $74,9 \%$ of them were working in schools where a school counselor is available.

\subsection{The Examination of the Scale's Validity}

Exploratory factor analysis was applied to examine the validity of the scale. 
Table 2. KMO and Bartlett Test Results of the Preschool Teacher's Guidance Qualifications Scale

\begin{tabular}{l|l|l}
\hline \multicolumn{2}{l|}{ Kaiser-Meyer-Olkin } &, 961 \\
\hline \multirow{3}{*}{ Bartlett } & Chi-square & 14830,332 \\
\cline { 2 - 3 } & $\mathrm{Sd}$ & 1711 \\
\cline { 2 - 3 } & $\mathrm{p}$ &, 000 \\
\hline
\end{tabular}

When Table 2 is examined, it can be seen that the Kaiser-Meyer-Olkin (K.M.O.) value is ,961. This situation is evaluated as "very good" according to the K.M.O criterion and it reveals that the number of data reached for the sample size is sufficient. When Bartlett's Test of Sphericity is examined, it is seen that Chi-square value is 14830,332 and significant at $\mathrm{p}<.01$ level. According to the results obtained here, it can be said that it is appropriate to perform factor analysis on the data.

In order to examine the factor structure of the "Preschool Teacher's Guidance Qualifications Scale", it was first subjected to factor analysis. Principal components factor analysis was used to test whether the scale was one-dimensional or not and as a result of the analysis, it was seen that 4 factors with eigenvalues of 1.5 and above appeared. Then, the factor weights of the items were examined and they were found out to have values above 0.45 . As a result of these operations, a scale consisting of 4 factors and 59 items was obtained. According to Buyukozturk (2002a), factor weights of .45 or above are accepted as a good standard for the selections that are made.

Table 3. Factor Analysis Results of the Preschool Teacher's Guidance Qualifications Scale (Rotated Component Matrix)

\begin{tabular}{|c|c|c|c|c|c|c|c|c|c|c|c|}
\hline Item No & Factor & 1 & 2 & 3 & 4 & Item No & Factor & 1 & 2 & 3 & 4 \\
\hline 53 & 1 & ,734 & & & & 16 & 2 & & ,554 & & \\
\hline 49 & 1 & ,691 & & & & 1 & 2 & &, 547 & & \\
\hline 52 & 1 & ,678 & & & & 11 & 2 & & ,509 & & \\
\hline 51 & 1 & ,635 & & & & 22 & 2 & & ,491 & & \\
\hline 64 & 1 & ,624 & & & & 63 & 3 & & & ,746 & \\
\hline 46 & 1 &, 592 & & & & 57 & 3 & & & ,686 & \\
\hline 32 & 1 &, 578 & & & & 48 & 3 & & & ,659 & \\
\hline 56 & 1 &, 574 & & & & 60 & 3 & & & ,635 & \\
\hline 37 & 1 &, 565 & & & & 58 & 3 & & &, 585 & \\
\hline 31 & 1 &, 555 & & & & 23 & 3 & & &, 581 & \\
\hline 54 & 1 &, 552 & & & & 68 & 3 & & &, 569 & \\
\hline 65 & 1 & ,540 & & & & 55 & 3 & & &, 553 & \\
\hline 69 & 1 &, 524 & & & & 50 & 3 & & &, 540 & \\
\hline 39 & 1 & ,518 & & & & 71 & 3 & & &, 533 & \\
\hline 43 & 1 &, 515 & & & & 66 & 3 & & &, 512 & \\
\hline 35 & 1 & ,490 & & & & 47 & 3 & & & ,493 & \\
\hline 67 & 1 & ,489 & & & & 21 & 3 & & & ,465 & \\
\hline 72 & 1 & ,484 & & & & 28 & 4 & & & & ,645 \\
\hline 7 & 2 & & ,689 & & & 29 & 4 & & & & ,599 \\
\hline 5 & 2 & & ,687 & & & 25 & 4 & & & &, 564 \\
\hline 6 & 2 & & ,664 & & & 33 & 4 & & & &, 562 \\
\hline 18 & 2 & & ,629 & & & 27 & 4 & & & &, 556 \\
\hline 17 & 2 & & ,618 & & & 30 & 4 & & & &, 550 \\
\hline 19 & 2 & & ,618 & & & 26 & 4 & & & &, 519 \\
\hline 15 & 2 & & ,613 & & & 42 & 4 & & & &, 506 \\
\hline 14 & 2 & & ,597 & & & 24 & 4 & & & & ,494 \\
\hline 13 & 2 & & ,595 & & & 41 & 4 & & & & ,456 \\
\hline 4 & 2 & &, 584 & & & 34 & 4 & & & &, 454 \\
\hline 8 & 2 & &, 574 & & & 36 & 4 & & & & ,453 \\
\hline 3 & 2 & &, 568 & & & & & & & & \\
\hline
\end{tabular}

When Table 3 is examined, it can be seen that as a result of the varimax rotation that is applied, items on the scale form a four-factored structure with 18 items in the first factor, 16 items in the second factor, 13 items in the third factor and 12 items in the fourth factor. The weight values of items in the first factor range from .734 to .484, weight values of items in the second factor range from .689 to .491, weight values of items in the third factor range from .746 to .465 and weight values of items in the fourth factor range from .645 to .453 . The factors were examined by the researchers and the first factor was named as "Supporting Educational Development and Interpersonal Relationships", second factor was named as "Supporting Individual Development and Orientation", third factor was named as "Self-acceptance, Support for Self and Social Development", and the fourth factor was named as "Recognizing Individual, Identifying Problems and Supporting Parents". 
Table 4. Expounded Total Variability

\begin{tabular}{|c|c|c|c|c|c|c|c|c|c|}
\hline \multirow[b]{2}{*}{ Component } & \multicolumn{3}{|c|}{ First Eigen values } & \multicolumn{3}{|c|}{ Sum of Squares } & \multicolumn{3}{|c|}{ Sum of Rotated Squares } \\
\hline & Total & $\begin{array}{l}\text { Variance } \\
\%\end{array}$ & $\begin{array}{l}\text { Cumulative } \\
\%\end{array}$ & Total & $\begin{array}{l}\text { Variance } \\
\%\end{array}$ & $\begin{array}{l}\text { Cumulative } \\
\%\end{array}$ & Total & $\begin{array}{l}\text { Variance } \\
\%\end{array}$ & $\begin{array}{l}\text { Cumulative } \\
\%\end{array}$ \\
\hline 1 & 26,579 & 45,050 & 45,050 & 26,579 & 45,050 & 45,050 & 9,879 & 16,744 & 16,744 \\
\hline 2 & 2,791 & 4,730 & 49,779 & 2,791 & 4,730 & 49,779 & 8,915 & 15,111 & 31,855 \\
\hline 3 & 2,165 & 3,669 & 53,448 & 2,165 & 3,669 & 53,448 & 7,373 & 12,496 & 44,351 \\
\hline 4 & 1,501 & 2,541 & 55,989 & 1,499 & 2,541 & 55,989 & 6,867 & 11,639 & 55,989 \\
\hline
\end{tabular}

When table 4 is analyzed, 4 factors are formed in the analysis done by selecting components with Eigen values of 1.5 and above. Principal component analysis is used as the extraction method. 4 factors explain 55.998 percent of the total variability. When the declared variance ratio is above $30 \%$, it is considered as sufficient for test development studies in behavioral sciences (Buyukozturk, 2002a).

Table 5. Pearson Correlation Coefficients Calculated to Test the Relationships between Factors and Their Relationship with the Total Point

\begin{tabular}{|c|c|c|c|c|c|c|}
\hline Factors & & Total & F1 & F2 & F3 & F4 \\
\hline \multirow{2}{*}{ Total } & $\mathrm{r}$ & 1 &, $937^{* *}$ &, $905^{* *}$ &, $853^{* *}$ &, $910^{* *}$ \\
\hline & Sig.(2-tailed) & &, 000 &, 000 &, 000 &, 000 \\
\hline \multirow{2}{*}{ F1 } & $\mathrm{r}$ & & 1 &, $794^{* *}$ &, $712^{* *}$ &, $854^{* *}$ \\
\hline & Sig.(2-tailed) & & &, 000 &, 000 &, 000 \\
\hline \multirow{2}{*}{ F2 } & $\mathrm{r}$ & & & 1 &, $698^{* *}$ &, $778^{* *}$ \\
\hline & Sig.(2-tailed) & & & &, 000 &, 000 \\
\hline \multirow{2}{*}{ F3 } & $\mathrm{r}$ & & & & 1 &, $702^{* *}$ \\
\hline & Sig.(2-tailed) & & & & &, 000 \\
\hline F4 & $\begin{array}{l}\mathrm{r} \\
\text { Sig.(2-tailed) }\end{array}$ & & & & & 1 \\
\hline
\end{tabular}

**. Correlation is significant at the 0.01 level (2-tailed).

When Table 5 is analyzed, it can be seen that the relationship between the sub-dimensions of the Preschool Teacher's Guidance Qualifications Scale and the relationship between sub-dimensions and the whole scale are significant at a level of .01. Correlation values ranging from 698 to 937 were found between the sub-dimensions of the scale and the total score. These findings indicate that there are no multivariate changes between factors. In other words, each factor measures a different structure. In this context, it can be said that the Preschool Teacher's Guidance Qualification Scale measures the characteristics that are desired to be measured.

According to these results, it was determined that all the sub-dimensions are related to the total scale and the sub-dimensions are related to each other as well. According to these statistical evaluations, it was determined that the test had construct validity.

\subsection{The Examination of the Scale's Reliability}

In order to examine the reliability of the scale, corrected item-total correlations, t-test results of upper and lower $27 \%$ groups, alpha coefficients for the total of the scale and its sub-dimensions and test-retest coefficients were analyzed.

In the scale, the independent groups t-test results between the scores of the upper $27 \%$ and the lower $27 \%$ groups Show that there's a significant difference for all items. In light of these findings, it can be said that each item of the "Guidance Qualifications Scale for Preschool Teacher Candidates" has the properties that can distinguish the guidance qualifications of preschool teacher candidates.

Table 6. Cronbach's Alpha Coefficients

\begin{tabular}{ll}
\hline Factors & Cronbach's Alpha \\
\hline Supporting Educational Development and Interpersonal Relationships &, 954 \\
Supporting Individual Development and Orientation &, 943 \\
Self-acceptance, Support for Self and Social Development &, 904 \\
Recognizing Individuals, Identifying Problems and Supporting Parents &, 909 \\
Total &, 977 \\
\hline
\end{tabular}

In Table 6, Cronbach Alpha values were calculated to examine the reliability of the total scale and its dimensions. As a result of the factor analysis, Cronbach's alpha coefficients were found to be .954 for the first factor, .943 for the second factor, .904 for the third factor and .909 for the fourth factor. Also, the Cronbach's Alpha coefficient obtained from the total scale was .977 ., It can be said that the scale is highly reliable with this structure. 


\subsection{Test-retest Reliability}

"Preschool Teacher's Guidance Qualifications Scale" was applied two times to a group of 44 people with three-week intervals and the relationship between two applications was identified. Table 7 presents the test-retest results.

Table 7. Test-Retest Reliability Coefficients of the Scale

\begin{tabular}{|c|c|c|c|c|c|}
\hline Factor & & $\mathrm{r}$ & $\mathrm{t}$ & sd & $\mathrm{p}$ \\
\hline F1 & Supporting Educational Development and Interpersonal Relationships & 0,915 & 108 & 43 & $\mathrm{p}<.01$ \\
\hline $\mathrm{F} 2$ & Supporting Individual Development and Orientation & 0,740 & ,334 & 43 & $\mathrm{p}<.01$ \\
\hline F3 & Self-acceptance, Support for Self and Social Development & 0,479 &, 714 & 43 & $\mathrm{p}<.01$ \\
\hline \multirow[t]{2}{*}{$\mathrm{F} 4$} & Recognizing Individuals, Identifying Problems and Supporting Parents & 0,952 & 064 & 43 & $\mathrm{p}<.01$ \\
\hline & TOTAL & 0,716 & ,366 & 43 & $\mathrm{p}<.01$ \\
\hline
\end{tabular}

As seen in Table 7, test-retest of the improved scale was applied to a group of 44 people with three-week intervals in order to identify the test-retest reliability score. It was determined that all the Pearson Correlation coefficients calculated in terms of factors between two applications were significant and that a relationship between test-retest was present. This result revealed that the scale had reliability in terms of time invariance.

\section{Results}

Factor analysis was carried out to identify the construct validity of the "Preschool Teacher's Guidance Qualifications Scale". As a result of this analysis it was seen that 4 factors with eigenvalue of 1,5 and above appeared. Then factor weights of the items were examined and it was seen that they were above 0,45 . At the end of these operations that were performed, the "Preschool Teacher's Guidance Qualifications Scale" consisting of 4 factors and 59 items was obtained.

As a result of varimax rotation, it was found out that the items on the scale have a four-factored structure which consist of 18 items in the first factor, 16 items in the second factor, 13 items in the third factor and 12 items in the fourth factor. It was also found out that the first, second, third and fourth factors explained $45,050 \%, 4,730 \%, 3,669 \%$ and $2,541 \%$ of the total variance of the scale, respectively. Also, the total variance explained by the four factors was found to be $55,989 \%$. There was a correlation value ranging from .689 to .937 between the sub-dimensions of the scale and the total score. According to these statistical evaluations, it was determined that the scale had construct validity.

It can be seen that the item-total correlation values of items in the scale range from .616 to .837 . Also, the t-test results between the upper $27 \%$ and the lower $27 \%$ groups were found to be significantly different for all items. Cronbach's Alpha values of the scale's dimensions were calculated. The Cronbach's Alpha coefficient of the first, second, third and fourth factors were $.954, .943, .904$ and .909 , respectively. In addition, the Cronbach's Alpha coefficient obtained from the total scale was .977 . The test-retest reliability coefficient of the scale was found to be .716 .

It can be assumed that the "Preschool Teacher's Guidance Qualifications Scale" developed within the scope of this research is a valid and reliable tool to identify the preschool teachers' competence levels in the guidance activities that they will perform in their classes with their own students and to determine their deficiencies. It is believed that the scale is going to fill an important gap in the field of preschool education.

When the literature is reviewed, it is seen that almost all the studies conducted in Turkey emphasize the importance of the guidance activities in the education process and express that guidance programs affect the general development of children in a positive way and that they are effective in accelerating the level of primary school preparation and readiness.

However, a measurement tool for determining the guidance qualifications of teachers working in the field of preschool education is not yet available in the literature of our country. In order for the teachers who work in the preschool period to be able to perform guidance activities and provide the necessary support to the guidance teachers, their qualification levels in this area must be determined and their qualifications must be improved.

Studies revealing the lack of guidance knowledge and experience of preschool teachers who are the practitioners of the guidance activities in the preschool education draw attention.

The preschool teachers who participated in Tekin's (2012) study indicated that they did not have enough information about guidance services for children and families and about child psychology and they emphasized that they needed in-service training in this area. On the other hand, Aliyev, Erguner-Tekinalp, Ulker and Shine-Edizer (2012), revealed in their study that administrators and psychological counselors working at preschool education institutions do not have enough knowledge and equipment to provide psychological counseling and guidance services in preschool education and they have taken a limited number of courses on the subject during their undergraduate education. Kilicoglu (2013), revealed that preschool teachers are inadequate in solving some problems and since there are not guidance teachers and counselors in every school, these problems remain unsolved, in her study on the determination of the educational needs 
of preschool teachers in carrying out effective guidance practices. According to a study carried out by Buyukgoncu in 2013, preschool teachers do not have a common understanding of techniques in getting to know an individual. Also, most of the preschool teachers need in-service training on techniques for getting to know an individual and almost half of them do not have enough knowledge to use these techniques. In the study conducted by Arslan Kilicoglu, it was determined that preschool teachers found themselves to be adequate to a great extent in the practices of personal and educational guidance but had partial deficiencies in the performance of vocational guidance activities. When evaluated in terms of some personal variables, the school type variable (whether the teachers are working in independent preschools or in primary school nursery classes) does not affect their perceptions of competence in terms of personal, educational and vocational guidance. The level of professional experience does not affect the teachers' perceptions of competence in terms of personal, educational and vocational guidance. The perceptions of the guidance qualifications of preschool teachers who find their guidance and counseling courses during their undergraduate education adequate are similar. Likewise, the perceptions of teachers who do not find their courses adequate during their education also show similarities.

Furthermore, preschool teachers were found to be inadequate in carrying out effective guidance practices and in the field of guidance in general (personal, educational and vocational guidance) when compared to the guidance teachers working at preschool education institutions. Especially in practices implemented by preschool teachers, it is believed that the mistakes made in the area of vocational guidance have a negative effect on the development of preschool education. Preschool teachers need to be supported in terms of method and practice in guidance services provided for students who need special education and their families. It was found out that preschool teachers were inadequate in response to the problems they encountered and that problems were left unsolved because of the lack of guidance counselors at each school. Families have expectations especially in terms of personal and professional guidance. It has been stated that preschool teachers who have the opportunity to work with counselors face fewer problems.

It is noteworthy that foreign-based studies in the field of preschool education also emphasize the importance of guidance services and the essential role of the teacher in these activities during the educational process. On the basis of developmental guidance, the role of the teacher in providing guidance services is quite important (Amatea, 2005). It is also seen that preschool teachers do not have enough knowledge about guidance services that must be provided for children and their families and about child psychology and that they need in-service training in this respect. It is worth stating that the majority of teachers demand that they also take part in the guidance services and that class guidance should be the responsibility of both teachers and psychological counselors. In addition, it is observed that administrators and guidance teachers who work at preschool education institutions also state that they do not have enough knowledge and experience to provide guidance services in preschool education and that they received a limited number of courses on this subject during their undergraduate education (Aliyev, 2012). Teachers appreciate and admire the role of school counselors but believe that guidance services need to be improved and enhanced (Reiner, 2009). Scruggs, Wasielewski and Ash (1999), included the opinions of parents, school staff and students on counselors in their study conducted with groups of children from preschool to 12 nd grade, and revealed that the majority of the school staff ( $76 \%$ ), parents (52\%) and secondary school students $(57 \%)$ who participated in the study believed that psychological counselors were engaged in other activities rather than counseling at school.

\section{References}

Akgun, E. (2010). Evaluation of guidance services in preschools from the point of view of preschool teachers. Primary Education Online, 9(2), 474-483. [Online]: http://ilkogretim-online.org.tr

Aliyev, R., Erguner-Tekinalp, B., Ulker, R., \& Shine-Edizer, F. (2012). The perceptions of school counselors and principals towards new psychological counseling and guidance services in early childhood education in Turkey. Educational Sciences: Theory \& Practice, Special Issue, 3083-3098. https://www.edam.com.tr/kuyeb/pdf/en/12_4_ozel_10_ramin_aliyev.pdf

Amatea, E., \& Clark, M. (2005). Changing schools, changing counselors: A qualitative study of school administrators' conceptions of the school counselor role. Professional School Counseling, 9(1), 16-27. https://doi.org/10.5330/prsc.9.1.w6357vn62n5328vp

Arslan, K. E. (2013). Determination of the training requirements of preschool education teachers in the effective realization of guidance practices. Unpublished Master's Thesis, Selcuk University, Institute of Social Sciences, Faculty of Child Development and House Management, Department of Child Development and Education, Konya.

Balci, A. (1997). Research in social sciences: method, technique and principles. Ankara: 72 TDFO Computer-Publishing Ind. Trade. Co. Ltd.

Basar, H. (2000). Education inspector. Ankara: PegemA Publishing. 
Bilgin, H. (2015). Determination of the guidance qualifications of prospective preschool teachers and a program study for the improvement of those qualifications. Unpublished Doctoral Thesis. Marmara University, Institute of Educational Sciences, Faculty of Primary Education, Preschool Teaching Department, Istanbul.

Buyukgoncu, N. (2013). Assessment of individual recognition techniques that are applied at preschool educational institutions in terms of teachers' opinions Unpublished Master's Thesis, Erciyes University, Kayseri.

Buyukozturk, S. (2002a). Hand book of data analysis. Ankara: Pegem A Publishing.

Buyukozturk, S. (2002b). Basic concepts of factor analysis and use of scale development, educational management in theory and practice. Ankara: PegemA Publishing.

Buyukozturk, S., Kilic, C. E., Akgun, O. E., Karadeniz, S., \& Demirel, F. (2012). Scientific research methods. Pegem Academy. Ankara.

Coakes, J. S. (2005). SPSS: Analysis Without Anguish: Version 12.0 for Windows, Jhon Wiley \& Sons, Australia. ISBN: 0470807369, 9780470807361

Demir, I. (2010). Preventive guidance services. Guidance for current and prospective teachers. Ankara: Pegem Academy

Dogan, S. (2001). How could psychological counselling and guidance services be structured at schools? VI. National Congress of Psychological Counselling and Guidance. Ankara: METU Faculty of Education.

Ergin, H. (2010). Guidance services and the teacher. Guidance for current and prospective teachers. Ankara: Pegem Academy

Ginter, E. J., Scalise, J. J., \& Presse, N. (1990). The elementary school counselor's role: Perceptions of teachers. The School Counselor, 38, 19-23.

Gokcakan, Z. (2008). The changing function of guidance and psychological counselling in education and the developmental guidance approach (ed. T. Bozkurt, M. Ulug and M.S. Ozden) Symposium Book of Educational Psychology.

Grant, N., \& Fabrigar, L. (2007). Exploratory factor analysis, encyclopedia of measurement and statistics, (Ed: Neil j. Salkind), California: SAGE Publications, Inc.

Hammond, D. (2005). Teaching as a profession: Lessons in teacher preparation and professional development, Phi Delta Kappan, 87(3), 237-240. https://doi.org/10.1177/003172170508700318

Hoffman, L. R. (1991). Developmental counseling for prekindergarten children: A preventive approach. Elementary School Guidance \& Counseling, 26(1), 56-67.

Kavuran, T. (2003). Problems encountered in the implementation of art teaching programs in faculties of education in Turkey and solution proposals, Firat University, Journal of Social Sciences, 13(2), 167-190.

Nazli, S. (2013). E-bulletin of psychological counselling at schools, a publication of the Commission of Psychological Counselling at Schools of the Turkish Psychological Counselling and Guidance Society, Izmir branch. Number 1 April. http://www.aktuelrehberlik.com/rhbrlk/bulten1-okulpsikolojikdanismanlik.pdf

NJDOE. (2004). New Jersey professional standards for teachers and school leaders. New Jersey: New Jersey Department of Education.

Reiner, S., Colbert, R., \& Pérusse, R. (2009). Teacher perceptions of the professional school counselor role: A national study. Professional School Counseling, 12(5), 324-332. https://doi.org/10.5330/PSC.n.2010-12.324

Scruggs, M. Y., Wasielewski, R. A., \& Ash, M. J. (1999). Comprehensive Evaluation of a K - 12 Counseling Program. Professional School Counseling, 2, 244-247.

Sen, H. S., \& Erisen, Y. (2002). Effective teaching characteristics of the members of faculty in institutions where teachers are trained. Gazi University, Gazi Faculty of Education Journal, 22(1), 99-116.

Tekin, G. (2012). Counseling and guidance services in early childhood education: The case of public preschools in Malatya, Turkey. US-China Education Review, 10, 875-880.

Yesilyaprak, B. (1995). Preschool education as the beginning of the professional development process. Istanbul: YA-PA.

Yesilyaprak, B. (2003). Guidance services in education. Ankara: Nobel Publications.

Yesilyaprak, B. (2004). Guidance services in education. Ankara: Nobel Publications.

Yesilyaprak, B. (2010). Guidance services in education. Ankara: Nobel Publishing House. 
Yuksel-Sahin, F. (2008). Assessment of psychological counselling and guidance services according to the opinions of students in secondary education. International Journal of Human Sciences,

http://www.insanbilimleri.com07.03.2009

\section{Copyrights}

Copyright for this article is retained by the author(s), with first publication rights granted to the journal.

This is an open-access article distributed under the terms and conditions of the Creative Commons Attribution license which permits unrestricted use, distribution, and reproduction in any medium, provided the original work is properly cited. 